\title{
The Role of University Libraries in Meeting Information Needs for Students and Lecturers: APortrait of Libraries in North Sumatra
}

\author{
Muhammad Dalimunte ${ }^{1}$, Kasron Nasution ${ }^{2}$, Toguan Rambe*3 \\ UIN Sumatera Utara, UIN Sumatera Utara ${ }^{1,2}$, IAIN Padangsidimpuan ${ }^{* 3}$ \\ Email: muhammadadalimunte@uinsu.ac.id ${ }^{1}$ kasronnasution@uinsu.ac.id ${ }^{2}$ \\ toguan@iain-padangsidimpuan.ac.id ${ }^{3}$
}

\begin{abstract}
Abstrak
Penelitian ini dilaksanakan di Sumatera Utara, dengan memilih tiga lokasi penelitan keseluruhannya dibawah naungan PTKIN (Perguruan Tingi Keagaman Islam Negeri) yakni Perpustakaan UIN Sumatera Utara Medan, IAIN Padangsidimpuan dan STAIN Mandailing Natal. Pemilihan lokasi ini didasarkan atas representasi perpustakaan perguruan tinggi keagamaan di Sumatera Utara. Ketiga perguruan tinggi tersebut memiliki karakteristik yang berbeda. Penelitian ini bertujuan untuk melihat potret perpustakaan perguraun tinggi di Sumatera Utara. Keberadaan perpustakaan sangat vital dalam meingkatkan kualitas akademik disebuah pergruan tinggi. Model penelitian yang digunakan adalah kualitatif, dengan melakukan penggalian data yang mendalam melalui sudut pandang informan, melalui FGD (Focus Group Disscussion), Observasi dan studi dokumentasi. Hasil penelitian menunjukkan bahwa terdapat tiga peran pengelola perpustakaan dalam mewujudkan sistem layanan informasi yang efektif di perpustakaan perguruan tinggi Sumatera Utara antara lain; memberikan pelayanan bimbingan kepada pemakai (user), memberikan layanan sirkulasi, memberikan layanan referensi, ditemukan juga kendala yang dihadapi misalkan sumber daya yang terbatas, sedangkan upaya pengelola perpustakaan mewujudkan sistem layanan informasi yang efektif yakni pelatihan bagi pengelola serta memperbaiki manajemen layanan.
\end{abstract}

Kata Kunci: Perpustakaan, perguruan tinggi, informasi, mahasiswa dan dosen, Sumatera Utara

\section{Abstract}

This research was conducted in North Sumatra, by selecting three research locations altogether under the auspices of PTKIN (State Islamic Religious High School) namely the Library of North Sumatra UIN Medan, IAIN Padangsidimpuan and STAIN Mandailing Natal. The selection of this location was based on the representation of religious college libraries in North Sumatra. The three universities have different characteristics. This study aims to see a portrait of a university library in 
North Sumatra. The existence of a library is very vital in improving the academic quality of a university. The research model used is qualitative, by extracting in-depth data from the point of view of informants, through FGD (Focus Group Discussion), Observation and documentation studies. The results show that there are three roles of library managers in realizing an effective information service system in university libraries. North Sumatra, among others; providing guidance services to users (users), providing circulation services, "providing reference services, alsoencountered obstacles, such as limited resources, while the efforts of library managers to realize an effective information service system, namely training for managers and improving service management.

Keywords: Library, College, Information Students and Lecturers North Sumatra

\section{INTRODUCTION}

Efforts to achieve the role of universities in the fields of education, research and community service, the presence of libraries has become a necessity. information media. In the Industrial Era 4.0, Universities must be ready and able to follow the development of the global flow of information so that the library can meet the information needs of researchers, students and lecturers as well as education staff. The existence of a university library is an important aspect in supporting the realization of the Tri Dharma of Higher Education. As a reference for one of the information centers, libraries are present in educational institutions, including universities. In college, of course, it is increasingly complex because it is not only used as reading material, but the reading material is also used as a research reference.

Another thing about the importance of libraries according to Law No. 43 of 2007 can be used as a juridical basis, contained in article 3 which explains the function of the library, among others, as a means of education, research, preservation, information and recreation to increase the intelligence and empowerment of the nation. Understanding of libraries will certainly differ greatly from the reality that occurs, including in university libraries. The impact of this reality makes the library still used as a repository of books and a mere complement to accreditation, even a more worrying adage that the library is actually used as a dumping ground for people with problems (Moh Mursid, Yogyakarta, 2013).

The university library's main purpose is to provide services to meet the 
information needs of teachers or lecturers as well as students. Therefore, university libraries must make maximum efforts in order to improve the quality of higher education. As far as the researchers observe about the difficulty of realizing the ideal library in NorthSumatra Province. Considering the number of universities in North Sumatra is very large, both public and private universities. Called the ideal library, of course, not only provides information services, but can also provide maximum service supported by various other facilities. Thus, the ideal library goal is to make all users feel comfortable and at home in the library. A university library is expected to have and complete books or information and can provide a conducive atmosphere. The existence of a library room is certainly not only clean, but also includes aspects of interaction and good communication between librarians and users. Because the needs and requests of users must be able to be provided by the librarian. Libraries must have a strategy in displaying a positive image, in order to maintaininteraction with the users they serve. Because a positive image can help the library conveythe characteristics and best quality of a college library. We can say that the positive imagedisplayed by the library is an ideal library.

The dynamics of a university library are so complex that it is interesting to do a research. Moreover, the initial observation that has been made by researchers is that there is a tendency for students to access information more often using cellphones to look for assignments from lecturers rather than using the library. This research focuses on highlighting the strategy and role of libraries in meeting information needs and improvingthe quality of higher education. This is because the university library is an effort to maintain and improve the efficiency and effectiveness of the academic process, including teaching and learning. With this research, it will also be seen that a well-organized and systematic library, directly or indirectly, can provide convenience for the academic process at the university where the library is located. This, of course, is closely related to progress in the aspect of education and with the improvement of teaching and learning methods which are felt to be inseparable from the problem of providing information facilities and educational facilities.

Several studies have been conducted in Indonesia related to university libraries, among others: Research by Junaeti and Agus Arwani (UPT Library STAIN Pekalongan) on The Role of Libraries in Improving the Quality of Higher Education. The article stated that one of the essential uses of a library is the 
availability of adequate collections and services. College libraries must be able to play an active role in carrying out the development of universities. An important objective of the library is to implement the Tri Dharma of Higher Education, to provide information services for learning, research and community service activities. The availability of complete information services in the library will also provide the librarian with the opportunity to utilize and develop knowledge independently.Another study was conducted by Taufik Kurniawan The Role of University Libraries in Developing Institutional Repositories. His findings say that university libraries are the shrimp of knowledge. It contains academic scientific papers which are useful information. Libraries in the digital era must have developed the concept of a repository to maximize library services. Libraries should be able to adapt and develop strategies to currentdevelopments in the digital era. This collection of digital information can be in the form of soft files or commonly known today as documents in PDF format (Portable Document Format) or in the form of images, videos, etc.

To test some of the research findings above, the study of the role of university libraries in North Sumatra is actually very interesting. Researchers believe that by using the theme of the role of libraries in this study, they can realistically reveal and explain university libraries in North Sumatra Province. Although it is well realized that the possibility of the condition of the university library being far from ideal is very possible, itwill be expected as a constructive effort in the future. In addition, this research is also part of an effort to complete various findings from previous studies with a wider scope.

\section{RESEARCH METHOD}

This study uses a qualitative approach where the type of research is phonemenology (exposure to phenomena), in the implementation of this research, it looks at the existence of university libraries in the province of North Sumatra. There are three libraries that are the overall object of research under the auspices of PTKIN (State Islamic Religious Higher Education) namely the North Sumatra UIN Medan Library, Padangsidimpuan IAIN Padangsidimpuan and Mandailing Natal STAIN. By choosing three libraries that are considered quite representative looking at the portrait of the library of religious colleges in this area, several things that underlie the choice of this location include the province is quite massive in the number of universities both public and private, the existence 
of libraries in loyal universities certainly has a very important role. which is quite central in advancing its institutions, or in a broader area of progress more broadly. There are three choices of libraries in the study, including the North Sumatra UIN Library,Padangsidimpuan IAIN and Mandailing Natal STAIN.

The first campus is certainly very interesting to study because it is geographicallylocated in the center of the province of North Sumatra, inevitably having to deal directly with the progress of libraries owned by other universities in the city of Medan. As for the IAIN Padangsidimpuan library, if you pay attention to it, it has experienced such asignificant development, its enthusiasm to switch status to a university must of course bein line with the development of its library. While the last one is STAIN Mandailing Natal. Even though the campus is still relatively young, it has changed its status to a state.However, all campuses should prepare reliable libraries in providing information services. Data collection in this study will be carried out by; 1) FGD (Focus Group Discussion), which is an interview activity with a group of people discussing a particularfocus on a problem or topic to see perceptions between individuals; 2) Direct observation of librarians, service patterns that occur in libraries, competence of human resources, completeness of reading collections for students, lecturers and researchers, activities inpromoting libraries to the wider community; 3) Documentation, where researchers collect data on university library activities to see a complete portrait of the existence of state Islamic campus libraries in North Sumatra. Data collection was carried out in three cities, namely Medan, Padangsimpuan and Panyabungan. The three regions represent the libraries of the North Sumatra State Islamic University, IAIN Padangsidimpuan and STAIN Mandailing Natal. Several informants were invited from each campus, including the head of the library, librarians, lecturers and students, to obtain the necessary data and descriptions of the portrait of university libraries in North Sumatra.

\section{RESULTS AND DISCUSSION}

The library can be understood as an academic institution whose main purpose is to provide information services to all users. However, each type of library in its development has different criteria and definitions from one type to another. One type of library that has been categorized is the university library. When referring to one definition of a university library, for example, as explained 
by Sulistyo Basuki, university libraries are located in higher education institutions, with the main goal of helping universities achieve their goals, namely the Tri Dharma of Higher Education or Education, Research and Community Service. In this regard, universities together with other work units participate in implementing the Tri Dharma of Higher Education, with the tasks of collecting, selecting, processing, caring for and serving the academic community as a whole.

In line with that, the university library will see the roles and functions carried out.At least the university library has functions, among others. Being the center of all educational programs at the University or other high schools. The university library is also a facility that helps the success of lectures and practicums held. In the library must store teaching aids or instructional material center. Next, the library should also be the storage and collection of all publishers for all existing scientific disciplines. The library should alsobe a center for cultural activities of the local community. The library visitors in the contextof the cultural activity center should not only consist of students, teachers, and institutional employees, but also people outside the university concerned.

Good and ideal library services are things that must be a priority, to increase the convenience of the users. The main task of a library is to collect, provide and provide information about the library to users, so that library managers provide user guidance services to users to be able to independent in conducting searches or retrieval of information quickly and precisely. To realize effective services quickly and precisely, the library provides a computer with an automation system that will make it easier for users to search for information. good by the university library. The university libraries, both in the libraries of UIN North Sumatra, IAIN Padangsidimpun and STAIN Mandaling Natal, these three universities use an open service system where the library manager will providedirect interaction with library users.

That means Direct meeting of users and library managers will result in users feeling that the services in the library are appropriate, according to the needs of users and can facilitate information retrieval, for that it is necessary to provide user guidance serviceseither directly or indirectly. Based on the results of observations and interviews. writers in the field related to the role of library managers in realizing an effective information service system in the library, including: Providing Guidance Services to Users Based on observations in the 
university library of North Sumatra Province in communicating and interacting with visitors all managers behave well, causing visitors very enthusiastic aboutthe library. In addition, the role of the manager in communicating with visitors or with all managers does not always use Indonesian, but sometimes uses regional languages, so that There was a close relationship between them, the manager explained the library rules andalso used the library catalog in a friendly manner, seeing them interact very well.

As can be seen from the results of the interview with Mrs. Siti Aisah as the head of the library at STAIN Mandaling Natal as follows:

"Upaya yang kami lakukan disini yakni seoptimalkan mungkin menjelaskan tata tertib peratruran di perpustakaan serta bagaimana menggunakan sistem katalog, dan selalumemberikan promosi yang baik kepada setiap pengguna, disamping itu senantiasa berkomunikasi dengan baik kepada semuan user. Pustakawan juga selalu dibekali menganai pelayanan yang baik kepada pustakawan. Bahkan sesama pengelola, atasan di perpustakaan dengan bawahan juga senantiasa berkoordinasi, selalu komitmen dengan program-program yang sudah dicanangkan, semuanya untuk mewujudkan visi dan misi yang telah ditetapkan. Karena yang menjadi pemahaman kita bersama bahwa, semua ketentuan yang sudah ditetapkan mestilah di implementasikan denganbaik".

The results of the interview above can be observed that the role of the manager is very beneficial for visitors by introducing library rules and regulations, how to use librarycatalogs, good reading, how to use and treat books inside and outside the library properly, how to find and browse books on checks. Explain to visitors about the existence and benefits of the library through the right moments. In addition, librarian managers must befriendly, and always want to help and help everyone who has problems, especially lookingfor information as life support daily.

The creation of a relationship between individuals in a society is the result of the process of social interaction carried out in it. The process of social interaction according toHerbert is when humans act on something on the basis of the meaning that something has for humans. it comes from the interaction between a person and each other. "And lastly, meaning is not fixed but can be changed, changes to meaning can occur through the processof interpretation that people do when they encounter something. This process is also known as the interpretive process. The college library is one of the places that has the potential for a social interaction to occur in it, namely the user with the librarian, the user and the user, and vice versa. a social interaction in it, namely the user with the 
librarian, the user and the user, and vice versa. The interaction process can occur in university libraries because the library is an institution for exchanging information. The same thing was also conveyed by Mr. Yusri Fahmi, the Head of the Library of IAIN Padangsidimpuanas follows:

"Kami senantiasa berupaya memberikan layanan yang terbaik kepada setiap pengunjung, baik dosen maupun para mahasiswa, layanan prima yang kami lakukan itu dengan membangun komunikasi yang baik, bahkan terkadang kami juga menggunakan bahasa daerah dengan pengguna. Hal ini dimaksudkan membangun interaksi yang intens kepada para pengguna".

Then the same thing was conveyed by Syukri Pulungan and Ricka Handayani as library visitors as follows:

"Bagi saya keadaan di perpustakaan suasananya sangat harmonis, terlihat dari cara mereka membangun komunikasi kepada kami kalau sedang mencari rujukan maupun referensi didalam perpustakaan, sikap yang ditampilkan oleh para pengelola juga sesuai dengan potret budaya di wilayah ini, mengedepankan kekeluargaan dan ramah tamah, ini kalau menurut hemat saya sangat penting, karna menggunakan potensi kearifan lokal yang ada dalam membangun citra positif suatu lembaga".

Based on the results of the interview above, the author sees that the communication and interaction built in the library always prioritizes existing cultural values, so that communication occurs more fluidly between managers and users. It is really necessary to be polite, friendly, and smiley to visitors so that visitors are interested again in coming to the library, and not saying rude things to fellow co-workers and visitors, to create a peaceful atmosphere.

\section{Providing Circulation Services}

Based on the results of observations in services at the Library of North Sumatra UIN Medan using a circulation service system in which the provision of assistance to library users in the process of providing information openly. So that visitors are free to choose the desired library materials from the library collections." visitors will feel satisfied because it is easy to find the necessary information materials. Efforts to provide clear information to all library users in an inclusive manner. This was conveyed by Azrai Hasibuan, one of the staff at the library of UIN North Sumatra Medan as follows:

"Di perpustaakan ini menggunkana layanan sirkulasi yang inklusif, seluruh pengguna yang mencari informasi di perpustakaan ini dapat mereka peroleh dalam waktu yang cepat, tugas kami juga sebagai pelayan pengguna perpustakaan harus memberikan informasi yang akurat sesuai kebuthan user, koleksi didalam 
perpustakaan ini sebenarnya sudah kami susun berdasarkan penomoran sesuai klasifikasinya. Tapi sering juga terjadi para pengguna perpustakaan kurang aktif, pengembalian buku yang sudah digunakan tidak berdasarkan klasifikasinya. Dalam hal ini memang kami akui perlu adanya terobosan memberikan edukasi kepada semua pengunjung, sebagai bentuk mewujudkan perpustakaan yang idela di UIN Sumatera Utara. Layanan inkusif yang diterapkan di UIN Sumatera Utara tidak membedakan umur, status sosial dan lain sebagainya, keseluruhannya mendapatkan perlakuan yang setara. Dalam konteks pelayanan yang kami lakukan di perpustakaan ini itu dapat dilihat jam operasional mulai pukul 07:3016.00 pada hari kerja. Karenanya setiap pengguna yang memasuki perpustakaan semestinya mematuhi semua peraturanyang telah ditetapkan".

The results of the interview above can be observed that the provision of circulation services to library users in order to fulfill the required information is carried out openly. With the circulation service, this is a place that serves the needs of visitors. directly with the library collection. In providing services, managers must be based on knowledge, skills, and attitudes. In addition, the manager is able to compete with services in other fields, and is able to foster a good sense of trust.

Circulation services are services related to the circulation of library materials owned by the library. In this circulation service, the process of borrowing library materialsthat may be borrowed is carried out, determining the loan period, returning borrowed library materials and making borrowing statistics to make library reports. lend non-book materials such as audio cassettes, video cassettes and others. Not all printed materials are loaned. The types of library materials that are commonly loaned are textbooks." There arealso libraries that lend old magazines (back issues). The loans are usually limited to library members, in this case lecturers, students and non-profit workers other educational institutions at the tertiary institution. Outside communities who are not members are usually not allowed to borrow. They are only allowed to read on the spot. The loan periodvaries from one library to another. another group of books. Generally, libraries lend their book collections for two weeks for ordinary book collections and one night for reserved collections.

Mr. Yusri Fahmi as the head of the IAIN Padangsidimpuan Library added the following as follows:

"Pada dasarnya semua pengguna perpustakaan itu ingin mendapatkan jawaban yang dihadapinya, dalam konteks ini adalah informasi. Baik informasi itu dalam bentuk digital maupun dalam bentuk tercetak. Perpustakaan maupun pengelola harus mampu mengatasi masalah tersebut, memahami semua yang dibutuhkan 
oleh user, bahkan harus bertanya kepada mereka bentuk informasi apa yang butuhkan, mendengar semua yang mereka kemukakan untuk perbaikan sebuah perpustakaan".

From the interview above, it can be concluded that the manager has digital knowledge and skills, including internet skills. With the mastery of the internet librarians can help visitors search quickly, precisely and accurately. In addition, reference service managers do not only provide materials references in the library only, but also must provide referral and direction services so that users find the information needed in other places/other libraries. patiently explained what the visitors were asking and needed. Because the staff realizes that the duty of a librarian is not only to provide libraries and books, but also to be ready to serve and assist those who need assistance. at the Tonggi Perhuan Library in North Sumatra using an open service system to make it easier for visitors to find books.

As stated by Mrs. Siti Aisah as head of the library at STAIN Mandailing Natal as follows:

"Apabila jenis referesni yang dibutuhkan pengguna itu tidak ada, maka kami akan membantu pengunjung mengakses sumber-sumber di tempat lain. Bagi anggota perpustakaan yang baru, biasanya kami memberika layanan pendampingan dan bimbingan. Mulai dari mengajak mereka untuk mengurus anggota kepesertaan perpustakaan, kemudian memberikan edukasi kepada mereka dalam hal memeanfaatkan semua fasilitas yang terdapat di perpustakaan. Semua kendala yang mereka hadapi kami sebaik mungkin memberikan pendampingan. Kalau ditemukan diantara pengguna yang kesulitan mendapatkan referensi yang ia inginkan, tentu itu merupakan tugas kami menyelesaikannya. Biasanya kondisi yang demikian membangun suasana yang baik antara pengelola dengan semua pengguna".

The results of the interview above can be seen that the manager always directs, refers, and helps visitors when experiencing difficulties in any case. The manager patiently explained what was asked and needed by the visitors themselves. Because the officers realize that their duty as a librarian is not only to provide libraries and books, but also to be ready to serve and help users who need assistance.

\section{Providing Reference Service}

Based on the results of observations in services at university libraries in North Sumatra, the role of the manager is also by providing reference services by providing explanations, answers, and information about something by showing 
the sources and how to find it. Reference services are provided on the basis of scientific knowledge. well, this isvery much needed by a manager in managing a library, without adequate knowledge a manager will not be able to manage a library properly. As stated by Mr. Azrai Hasibuan Meidiana as service staff at the UIN North Sumatra Library as follows:

"Basic ilmu pengetahuan terkait dengan perpustakaan sangat begitu penting dalam menjalankan tugas didalam perpustakaan, mulai dari memberikan jawaban serta penjelasan terhadap informasi yang dibutuhkan oleh setiap pengguna perpustakaan.Memang secara teknis yang terjadi bahwa didalam perpustakaan itu tidak semuanya dan selamanya memiliki kualifikasi pendidikan perpustakaan, perbedaan ini memangharuslah dilakukan pelatihan dan kerjasama yang baik antar individu yang ada. Karena itu penguasaan terhadap teknologi sangatlah mutlak dikausi oleh pustakawan apapun latar belakang pendidikan mereka. Karena kita sangat yakin dengan menguasai teknologi maka akan sangat cepat bagi semua ntuk mempromosikan perpsutakaan, kita disini ada website yang isinya memang seluruh dokumen dan kegiatan yang telah dilakukan dierpustakaan dan semua pegawai sangat memahami ini".

From the results of the interviews above, it can be seen that the reference serviceis carried out by the manager by providing assistance to library users to find information. For this reason, managers are required to have good knowledge by knowing sources and how to search for information needed by users. The same thing was also conveyed by Mr.Abdi Mubarak Syam as a visitor to the UIN North Sumatra Medan Library as follows:

"Pengalaman saya saya saat berkunjung ke perpustakaan ini, yang saya lihat bahwa mereka sudah sangat menguasai teknologi, misalkan komputer memang sudah sangatwajib bisa dioperasikan seorang pustakawan, kalau tidak pasti mereka akan kesulitan dalam bekerja. Karenaya pelatihan yang dilakuakn tentu semakin meningkatkan kemampuan mereka dalam menguasai bidang mereka terkhusus penguasaan teknologi".

From the description above, the writer can conclude that the knowledge possessed by the manager will certainly have a good impact on the users, this is evidenced by the improvement in the service system provided by the manager. From the explanation above, it can be concluded that there are three roles of library managers in realizing an effective information service system in the university library of North Sumatra province, including; Providing Guidance Services to Users (users), where managers explain library rules and also use catalogs. library in a friendly manner, seeing them interact very well; Providing Circulation Services, which provides assistance to library users so that visitors 
are free to choose the desired library materials from the library collections; Providing Reference Services, which provides reference services by providing explanations, answers, or information about something by showing its sources and how to find it on a good scientific basis.

\section{Obstacles Faced by Library Managers in Realizing an Effective Information Service System in the University Libraries of North Sumatra}

The services provided to users are not as easy as perceived by service providers, there are still some obstacles or obstacles faced by library managers in realizing an effective information service system at the North Suatera College Library:

\section{Limited Resource Quality}

Limited human resources and lack of knowledge are the causes of obstacles in realizing an effective information service system. The human resources in question are library managers. From the observations, the authors found that there is a shortage of human resources with scientific disciplines in the field of library management. people alone, resulting in ineffective services, conditions like these cause not to focus on library management. As stated by Mrs. Siti Aisyah, the service at the STAIN Mandailing Natal Library is as follows:

"Memang kenyataan yang ada pengelola disini masih banyak yang dalam pembelajaran, atau masih berdasarkan pengalaman saja, karena tidak semuanya memiliki kualifikasi pendidikan ilmu perpustakaan. Pendidikan yang beraneka ragam membuat ini menjadi tantangan tersendiri untuk melakukan manajemen yang baik. Akan tetapi bagiamanapun tentunya kami semua merangkul sebagai satu tim yang mempunayai visi yang sama. Saliang belajar dan bekerjasama untuk meciptakan layanan perpustakaan yang efektif".

The results of the author's interview above can be observed that, apart from thosewho still rely on a few people, there are also managers who are elderly so that their capacityis limited. For this reason, it is necessary to provide guidance to all effective library managers so that they can participate in providing effective services. for the users. "Participation is an important factor in supporting effective management, therefore it is necessary to have the participation of all office holders in the University Library of North Sumatra so that it will increase the sense of responsibility so that they can work efficiently and effectively. Mr. Yusri as the head of the IAIN Padangsidimpuan library said as follows: 
"Tingkat pendidian memang sangat penting, karena itu mungkin ini menjadi masukan nantinya kepada pimpinan untuk merekrut pegawai yang secara kualifikasi sesuai dengan pendidikan itu sendiri. Memang masih sangat banyak yang harus diperbaiki, tapi karena berdasarkan program kerja yang dijalankan tentu akan memberikan dampak yang positif terhadap kemuajuan lambaga ini, tentunya sangat diperluan terobosan pegawai yang ada di perpustakaan ini, agar SDM disini juga cepat berkembang".

The results of the author's interview above can be observed that the level of education has a very large impact on performance in providing effective services so that the skills and expertise possessed by the managers will improve. In addition, some of the managers are not aware of their rights and obligations as managers. As stated by Aditian as a user at the UIN North Sumatra Library as follows:

"Pengetahuan mungkin masih harus diupgrade terus, karena sewaktu kami berkunjung ke perpustakaan mau meminta memcarikan informasi yan gsedang kamibutuhkan, prosedurnya masih banyak kadang harus meunggu, masih banyak juga diantara merka yang saling bertanya, jadi kita juga mersa bingun dan sudah menghabiskan waktu pastinya jadi perlu peningkatan dan manjemen yang baik menyangkut masalah ini".

The results of the author's interview above can be observed that, in terms of management, the same weaknesses are also encountered and the problem that hinders thedevelopment of libraries from the manager's side is that knowledge, skills, and abilities are still completely inadequate. For that, it is necessary for managers to improve knowledge and skills.

\section{Slow Impressed Administration}

Based on the results of observations in the University Library of North Sumatra, it was found that the administration system seemed slow due to resources that did not understand technology, which became an obstacle in realizing an effective information service system. As stated by Mrs. Sarah Wulandari as a service staff at the STAIN Mandailing Natal Library as follows:

"Yang kami lakukan selalu memberikan layanan yang paling baik terhadap semua pengguna, meskipun masih ada ditemukan kekurangn dalam segi keahlian pegawai perpustakaan memberikan layanan infomasi dan administratif yang cepat dan akurat kepada semua pengguna. Dilain hal kami juga menyediakan layanan website yang kami selalau update dan selalu bisa diakses oleh siapapun, kami juga sediakan bahan referensi didalamnya, karena sumber informasi itu tidak harus yang tercetak akan tetapi mesti ada juga yang digital. Dengan media ini kami mengharapkan para pengguna itu lebih memudahkan dalam memenuhi informasi yang mereka butuhkan". 
As can be seen from the results of the interview with Ms. Zuraida as a staff at the IAIN Padangsidimpuan Library as follows;

"Secara teknis, kami disini memberikan hak akses kepada pemustaka seluas-luasnya melalui internet. Seluruh program bahkan kemuajuan perpustakaan IAIN Padangsidimpuan dapat semua dilihat diinternet, memang peserta harus mendaftar terlebih dahulu, mengenai prosedur pendaftarannya sudah kami jelaskan di website tersebut. Masalah penguasaan teknologi, memang tidak semua kemampuannya merata dalam penguasaan teknologi, hal ini dipengaruhi keilmuan yang berbeda-beda anatar sesama. Maka memaag sangat perlu penambahan sumber daya menusia untuk dapat mengisi semua lini pekerjaan didalam perpustakaan".

The results of the interview above can be observed that the university library in North Sumatra has provided information that can be accessed via the internet so that visitors do not need to be difficult to come, by accessing the official website, visitors will be able to get the information they need.

\section{Limited Facilities and Infrastructure}

The obstacles in managing the library in terms of suggestions and infrastructure such as lights that sometimes go out, as conveyed by Titi Martini Harahap as a service staff at the STAIN Mandailing Natal Library are as follows:

Masalah yang begitu krusial yang dihadapi sewaktu melakukan penelusuran informasi yaitu apabila listrik padam, tentu sistem tidak dapat dioperasikan. Kondisi ini tentu memaksa kami sebagai pengelola untuk meningkatkan saranadan prasarana di kampus ini. Para pemustaka tentu sangat tidak senang bahkan tdak puas katika hal ini terjadi, akan tetapi kami senantiasa berupaya samaksimal mungkin.

The same thing was also conveyed by Mr. Yusri Fahmi as the head of the IAIN Padangsidimpuan library stating the following:

Masalah listrik terkadang kami juga megalami disini, pemadaman secara mendadak yang dilakukan oleh petugas dari PLN tentu mengganggu aktivitas layanan di perpustakaan. Memang kita juga komplein, namun jawaban mereka sedang dalam perawatan atau lagi diperbaiki. Kita memang sudah ada disel, namun tentu masih kurang efektif untuk memenuhi kebutuhan listrik yang adadi dalam perpustakaan.

The results of the author's interview above can be observed that the obstacle that sometimes occurs is the blackout in the university library of North Sumatra, this is due to repairs or short-circuits to the flow to the library, even though this obstacle can still be overcome by using diesel in the library, although there are several electricity lines that mustbe turned off in order to provide first- 
class service to visitors or visitors. From the explanation above, it can be seen that there are three obstacles in realizing an effective information service system in the university library of North Sumatra, including; Limited Quality of Resources, where the ability of managers is still limited so they often rely on others to complete their work; Administration That Seems Slow, where the administration system seems slow due to resources that do not understand technologybecomes an obstacle in realizing an effective information service system; and Lack of Library Management, where the arrangement of libraries in terms of advice and infrastructure is still an obstacle because managers are late for work and the lights sometimes go out, so that users who want to need information have to be hampered.

\section{Efforts of Library Management in Realizing an Effective Information Service System inthe University Libraries of North Sumatra}

The progress of a library is determined by the library manager who manages the library itself. All facilities and infrastructure, all collections are managed by the manager. If everything is managed properly then the comfort and satisfaction felt by library users. optimally in carrying out its duties and functions. Thus, the manager becomes the spearhead of success in disseminating information in the library.

In Law No. 43 of 2007 concerning library science, it is also stated that the manager is someone who has the competence obtained through librarianship education and/or training and has the duties and responsibilities to carry out library management and services. The main role of the manager (library manager) in managing the information contained in a library, strive for the best for users so that these conditions can be used more broadly by the academic community concerned. according to needs. The more up-to-date information you have, the more library users will be interested in using library services. Based on the results of the author's observations and interviews in the field, it can be seen that the efforts of library managers in realizing an effective information service system in the university library of North Sumatra are as follows:

\section{Training for Managers}

There are managers who have sufficient ability to carry out routine tasks that are increasingly large and complex, which will help advance the 
development of libraries in all fields. The training that has been carried out by library managers is librarianship training in the campus environment. effective in the library in the future, it is required that sufficient manpower is available in terms of quantity and quality, especially the quality of service to the library. As stated by Mr. Yusri Fahmi as the head of the IAIN Padangsidimpuan Library stated as follows:

"Terakhir kami melakukan Pelatihan Kepustakawanan di kampus kami dengan menghadirkan narasumber dari intansi luar tahun 2020. Kegiatan tersebut sangatlah penting untuk meningkatkan kemampuan para pustakawan disini. Maka program yang kami lakukan adalah mengadakan pelatihan dan study tour ke perpustakaan nasional. Disamping itu kami juga melakukan kerjasama dengan pemerintahan setempat dalam hal promosi perpustakaan serta menysunn program untuk mengetahui kebutuhan informasi masyarakat".

The results of the author's interview above can be observed that managers can grow and develop as individuals who are sure to take on greater responsibilities if they have good insight and ability, this will have an impact on the quality of their services and work as community servants. As stated by Mrs. Sarah Wulandari as a service staff at the STAIN Mandailing Natal Library as follows:

"Evaluasi yang kami lakukan terhadapat pustakawan yakni mengenai bidang kerjanya dan hasil kinerja pegawai yang bersangkutan. Dalam penempatan kami pengelola juga melihat kemamapuan dan bidangnya masing-masing. Dalam peningkatan kinerja pegawai kami juga melakukan pelatihan sumber daya manusia. Pelatihan yang dilakukan sangat dirasakan manfaatnya untuk kemajuan perpustakaan ini, ditambah lagi untuk memacu semangat para pegawai perpustakaan. Kegiatan-kegiatan webinar juga marak kami lakukan dengan mengahadirkan pembicara dari pusat untuk mengedukasi kami di perpustakaan ini".

The results of the author's interview above can be observed that training is very helpful in improving the quality in the library, in addition to reducing work saturation, to seek experience, and as a provision in the event of a task shift, making it possible to develop new things on the assigned task. according to their respective expertise and experience. With the training, it is also intended that managers in Higher Education Libraries in North Sumatra have adequate insight and professional skills in order to realize an effective information service system in the library. This is intended to motivate administrators to actively participate in library activities. Thus, it is hoped that the University Library of North Sumatra will be more advanced and developed in 
accordance with the common goal. As stated by Mr. Azrai Hasibuan as a service staff at the UIN North Sumatra Library as follows:

"Pegawai yang professional merupakan capaian ideal untuk kemajuan suatu lembaga yang ada, capain kinerja yang telah dimiliki setiap pegawai tentu sangat perlu untuk dievaluasi, dan memberikan solusi yang terbaik untuk kemajuan kedepan. Semuanya memang harus mengupgrad kemampuan dan skillnya dalam memberikan layanan informasi di perpustakaan. Kami sebagai pimpinanmisalnya menerapkan sistem peraturan kehadiran kerja dan capaian kinerja setiapminggunya. Jadi berdasarkan laporan mingguan tersebut akan lebih mudah untuk dilakuakn evaluasi secara komfrehensif".

The results of the author's interview above can be observed that, the University Library in North Sumatra seeks to change behavior and beliefs and raise awareness in the community, with the experience gained by the manager and also the training received, themanager's performance from day to day looks a little better even though there are shortages here and there. However, having the initiative to change is an achievement thatcan improve and realize an effective information service system in University Libraries in North Sumatra.

\section{Work Discipline Arrangements}

Through work discipline arrangements, it is intended that library managers incarrying out their daily tasks are always obedient and obedient to the vision and mission of the library itself. As stated by Mrs. Sarah Wulandari as a service staff at the STAIN Mandailing Natal Library as follows:

"Disiplin kerja yang diterapkan tentu sangat mampu memberikan layanan administrative yang begitu cepat, karena pada umumnya semua pencari informasi di perpustakaan ini semuanya ingin secara cepat dan mudah didapatkan. Karena itu kami bekerja sesuai dengan beban kerja yang ada, menampilkan disiplin kinerjasetiap harinya. Dengan begitu upaya memberikan pelayanan yang terbaik di perpustakaan sangatlah mungkin terjadi".

The results of the author's interview above can be observed that, by improving work discipline so that library managers are getting better, then library managers will be able to provide their role, so that visitors will believe and be happy with the performance of library managers and have a positive impact on performance. which was conveyed by Mr. Yusri Fahmi as head of the IAIN Padangsidimpuan Library stated as follows:

"Kami dalam bekerja melayani pemustaka di sisini sesuai dengan ketentuan. Alur pekerjaannya sudah sangat tertib karena mengikuti jobdesk masing-masing pegawai, meskipun tentu masih didapati beberapa kekurangan yang terjadi, 
pelayanan administrative memang sesuatu yang begitu vital dalam meningkatkan mutu perpustakaan".

The results of the author's interview above can be observed that the awareness instilled by library managers provides improvements that make it easier for visitors to get the information they need. to apply discipline within each of them.

\section{Improving Facilities and Infrastructure}

In an effective information service system at the University Library of North Sumatra, what is most needed is planning in library management where planning is a thought about the future based on expectations in its implementation there are actions that are considered necessary to achieve goals. In essence, planning is a decision-making process that forms the basis for future activities. "Library planning generally consists of library objectives, strategies used, potential problems to be faced and how to overcome them, organizational structure, and how to maintain them until they are achieved. library expectations. For this reason, it is necessary to have a precise and measurable concept. As stated by Mr. Azrai Hasibuan, the library staff at UIN North Sumatra, Medan, is as follows:

"Sebenarnya kami sudah ada konsep pelayanan diperpustakaan ini, dalam menerapkan hal tersebut memang sangat perlu dilakukan suvey mengenai kepuasan pengguna perpustakaan ini, sehinga dapat menjaring apa yag menjadi kendala dan kekurangan dalam menjalankan layanan di perpustakaan. Ini memang lebih akurat dalam melakukan perbaikan dimasa depan".

The results of the author's interview above can be observed that in managing the library, itis necessary to improve facilities in meeting the wishes of the community. For that, good and correct planning is needed. As stated by Mrs. Siti Aisah Eli, service staff at the STAINMandailing Natal Library as follows:

"Perencanaan memang hal penting dalam mambangun manjemen yang baik, seandainya perencanaan tidak bagus jelas kan berdampak kepada lembaga, dalam perpustakaan ini manajemen layanan sangat penting. Maka bangunan manajmen yang dilakukan yakni pedoman visi dan misi perpustkaan itu sendiri. Sehingga capaian kedepannya akan sejalan dengan perkembangan perguruan tinggi tersebut".

The results of the author's interview above can be observed that, the establishment of a mature goal, will help in realizing an effective information service system in the university library of North Sumatra. For this reason, it is necessary to have good planning." From the explanation above, it can be 
concluded that there are three efforts by library managers in realizing an effective information service system in the university library of North Sumatra, where by participating in training and also study tours in order to improve the ability of managers in carrying out their duties. routine tasks that are becoming more numerous and complex so that they can help advance the developmentof libraries in order to realize effective services; work discipline arrangements, where library managers in carrying out their daily tasks are always obedient and obedient to the vision and mission of the library so that administrative services can be completed properly and improve management, where by planning in library management to realize an effective information service system in accordance with with the vision and mission of theuniversity library in North Sumatra.

\section{CONCLUSION}

Based on the results of research and discussion on the phenomenon of university libraries in the province of North Sumatra in providing good information services to lecturers and students at the University of North Sumatra, Medan, IAIN Padangsidimpuan and STAIN Mandailing Natal, in general, have been going well but their performance needs to be improved. Therefore, in particular, some research conclusions can be drawn asfollows: 1) There are three roles of library managers in realizing an effective information service system in the University Library of North Sumatra, among others; Providing Guidance Services to Users, where the manager explains the library rulesand also uses the library catalog in a friendly manner, "when seeing them interact it is very good; Providing Circulation Services, which provides assistance to library users so that visitors are free to choose materials desired library from the range of library collections; Providing Reference Services, which provides reference services by providing explanations, answers, as well as information about something by showing its sources and how to find it on a good scientific basis; 2) There are three obstacles in realizing an effective information service system at the University Library of North Sumatra, including; Quality of Limited Resources, where the ability of managers is still limited so they often rely on others to completetheir work; Administration that seems slow, in where the administrative system seems slow due to resources that do not understand technology to be an obstacle in realizing an effective information service system; and Lack of Library Management, where library arrangements in terms of advice and infrastructure 
are still an obstacle because managers are late for work and sometimes lights die," so that users who want to need information have to be blocked; 3) There are two efforts by library managers in realizing an effective information service system in the University Library of North Sumatra, including; Training for Managers, where by participating in training such as managing libraries, both collections and services as well as study tours in order to improve the ability of managers to carry out routine tasks that are increasingly large and complex so that they can help advance the development of libraries in order to realize effective services and improve management. Whereas by planning in library management in order to realize an effective information service system in accordance with the vision and mission of the university library. 


\section{REFERENCES}

Ahmadi, Abu, Supriyono, Widodo, (2004). Psikologi Belajar. Jakarta Rineka Cipta.

Badan Standardisasi Nasional, PSN 08-2007, (2007). Penulisan Standar Nasional Indonesia, Jakarta:Gedung Manggala Wanabakti

Buckland, Michael K. (1988). Library Services in Theory and Contetxt. 2nd ed. Oxford:Pergamon

Carlson NR. Buskist W. (1997). Psychology: the science of behavior

Fahrizandi, (2020). Pemanfaatan Teknologi Informasi di Perpustakaan, Jurnal Ilmu Perpustakaan dan Informasi, http://journal.iaincurup.ac.id/index.php/TI/article/view/1160. 4 (1) 1. $65-75$

Hmad A K.Muda, (2016).Kamus Lengkap Bahasa Indonesia, Jakarta: Reality Publisher

Ibrahim A. (1999). Pengelolaan Perpustakaan Sekolah. Jakarta : Bumi Aksara

Ibrahim, (2014). Konsep Dasar Manajemen Perpustakaan Dalam Mewujudkan Mutu Layanan Prima Dengan Sistem Temu Kembali Informasi Berbasis Digital. Khazanah Al-Hikmah: Jurnal Ilmu Perpustakaan, Informasi dan Kearsipan, http://journal.uin-alauddin.ac.id/index.php/khizanah-alhikmah/article/view/147. 2 (2) 129-138

Lesk, M. Understanding Digital Library $2^{\text {nd }}$ Ed. San Fransisco : Morgan Kauffman, 2005

Makmur, Testiani, (2015). Perpustakaan Era Keterbukaan Informasi Publik. Yogyakarta: Graha Ilmu

Nugrohoadhi, A. (2013). Menakar Peranan Pustakawan Dalam Implementasi Teknologi Informasi Di Perpustakaan. Jurnal Khizanah Al-Hikmah, http://journal.uin-alauddin.ac.id/index.php/khizanah-alhikmah/article/view/34. 1(2), 101- 114.

Piliang, Y. A. (2013). Masyarakat Informasi dan Teknologo (Teknologi Informasi dan Perubahan Sosial). Sosio teknologi, Jawan Barat: Institut Teknologi Bandung, https://multisite.itb.ac.id/kkik-fsrd/wpcontent/uploads/sites/154/2007/04/1.P.-Yasraf.pdf. Vol,12, Hal. 143- 156. 
Sabri, A. 2000Pengantar Psikologi Umum \& Perkembangan. Jakarta : Pedoman Ilmu Jaya.

Saleh A.R. (1994).Pelayanan Sirkulasi Dan Referensi, Bogor: Fakultas Pertanian InstitutPertanian,

Sri Sularsih, (2011). Standar Nasional Perpustakaan (SNP), Jakarta: Perpustakaan RI,

Sugiyono, (2009). Metode Penelitian Kuantitatif Kualitatif dan $R \mathcal{E} D$, Bandung: Alfabeta

Taufiqurokhman, (2011). Kebijakan Publik, Jakarta: Fakultas Ilmu Sosial dan Ilmu Politik UniversitasMoestopo Beragama (PERS)

Tjitropranoto, Prabowo (1995). Penelitian dan Sumber Daya Manusia di Bidang Perpustakaan. Jurnal Perpustakaan Pertanian, IV (1), 1995: hal 1-9. Bogor: Pusat Perpustakaan Pertanian danKomunikasi Penelitian.

Umar, (2011). Metode Penelitian Untuk Skripsi dan Tesis Bisnis, Jakarta: PT Raja Grafindo Persada

Utami Munandar, (2000). Pengembangan kreativitas Anak berbakat, Jakarta,

Yamin, M. (2009). Metodologi Penelitian Pendidikan dan Sosial Kualitatif dan Kuantitatif, Jakarta:Komplek Kejaksaan Agung, Cipaayung

Yuliatry Bunga, Standar Pelayanan Perpustakaan dan Informasi Bidang Layanan Koleksi Umum, Jakarta: Perpustakaan Nasional RI, 2015

Yusuf, Pawit M, (2000). Layanan Perpustakaan dan Informasi. Bandung: JIP FIKOM UniversitasPadjadjan

Yusuf, Pawit, (2013). IlmuInformasi, Komunikasidan Kepustakaan. Jakarta: Bumi Aksara, 